\title{
Safety Risk Management in Production Process: A case study in the automotive supplier industry
}

\author{
A.A. Bazdar ${ }^{1}$, N. Jadidi ${ }^{*}$ \\ 1. Industrial Engineering, University of Technology Golpayegan, Golpayegan, Iran
}

\begin{abstract}
This paper deals with the study of reliability measures of a complex engineering system consisting three subsystems namely L, $\mathrm{M}$, and $\mathrm{N}$ in series configuration. The subsystem-L has three units working under 1-out-of-3: G; policy, the subsystem-M has two units working under 1-out-of-2: G policy and the subsystem-N has one unit working under 1-out-of-1: G; policy. Moreover, the system may face catastrophic failure at any time t. The failure rates of units of all subsystems are constant and assumed to follow the exponential distribution however, their repair supports two types of distribution namely general distribution and Gumbel-Hougaard family copula distribution. The system is analyzed by using the supplementary variable technique, Laplace transformation and Gumbel-Hougaard family of copula to derive the differential equations and to obtain important reliability characteristics such as availability of the system, reliability of the system, MTTF, and profit analysis. The numerical results for reliability, availability, MTTF, and profit function are obtained by taking particular values of various parameters and repair cost using maple. Tables and figures demonstrate the computed results and conclude that copula repair is more effective repair policy for better performance of repairable systems. It gives a new aspect to scientific community to adopt multi-dimension repair in form of copula. Furthermore, the results of the model are beneficial for system engineers and designers, reliability and maintenance managers.
\end{abstract}

Keyword: K-out-of-n, G system, Availability, MTTF, Catastrophic failure, Gumbel-Hougaard family copula distribution.

\section{The Literature Review}

Most of the quality problems in the production industry are rooted in the lack of risk management and failure modes and effects analysis which result in producing a defective product and finally cause customer dissatisfaction. There are different ways to risk evaluation divided into qualitative and quantitative methods. In both of the mentioned approaches, potential failures for people, materials, equipments, and environment are evaluated. So many studies in failure modes and effects analysis (FMEA) have been investigated which provided practical guidelines to remove the failures. Yousefi et al. provided a new analytical approach (RDEA) to evaluate and prioritize environment failures in different industries in 2018. This approach has covered the defects of the traditional scoring system of priority risk number in failure modes and effects analysis which neglected safety principles in the production process [1]. Also, Geo et al. used developing quality functions. They were studied customer needs to find the importance of production process factors and reform it based on failure modes and effects analysis. Finally, they were determined the

\footnotetext{
* Corresponding Author Email: nasimjadidi97@yahoo.com
}

comprehensive importance of production process factors and installed a kind of shaft in a shipping factory [2]. Vang and et al. provided a new approach based on the cognitive procedure of decision-makers and its risks to evaluate the risks and prioritize them [3].

Some other studies have been done using fault tree analysis such as electronic paper display, DempsterShafer evidence theory, and grey relational projection method in risk evaluation and management caused a better understanding of the organization risks. Their related activities are mutual effects of risks identification, the cognition of the possibilities and suspicions which must be controlled in all management levels, providing data and information for investment decision making, the financial effects evaluation on the investments, policymaking over loaning, marketing, etc. $[4,5,6]$.

There are many reasons such as customer needs progressing, producer's competitiveness, and their alignment with rapid changes in technology that have been resulted in increasing in requirements of manufacturing processes. In such conditions, any defect or shortages in the production line will cause the loss of marketing. If the risks of the manufacturing process 
have not been evaluated, choosing the suitable approach to decrease the risk of failure in the production line will be difficult. Moreover, there are a lot of safety risks that are rarely considered in industries. So this shortage can be caused many failures in raw materials inspection, the efficiency of equipment and human forces and finally can be caused the big failure in industry mission.

There are many various methods to investigate and assessment of production risks such as process failure modes and effect analysis which have the highest application with production activities and organizational structure that have been as well as considering with safety principles. Yong et al. (2018) applied the FMEA with weighted entropy to analyze data gained from the filling station. They can be calculated risk priority number that resulted in type of failure and its sources [7]. In the other study, to minimize the potential failure, researchers found a procedure to manage the risk of information security in which consists of FMEA and fuzzy theory. Because of the propagation of internet usage, there is a lot of vulnerability in organizations which is resulted from information technology assaults. These assaults lead to missing data and discounting in manufacturing and services processes (Silva et al. 2014) [8]. In 2019, the specific procedure has been proposed by Mangeli et al. which used logarithmic fuzzy preference programming to make indexes and weighted variables without fuzzy ranking. Also, they combined support vector machine and fuzzy logic to assess safety risks in organizations [9]. Specific et al. reviewed FMEA critically. Nevertheless, this approach is still studied by researchers in universities there isn't any solution to solve problems that can be resulted from potential safety risks [10]. A lot of investigation has been done on railroad transportation in Zilina University about limitations of this part of the supply chain. The effort is done through combine Saaty MCDM with FMEA [11]. Although the aforementioned articles make many contributions to risk assessment, there is a lot of research gap identification in risk management methods that are investigated between 2014 and 2018. Villarini et al. provided a comprehensive study about risk assessment by maintenance and repairing planning to improve reliability assessment [12]. A new approach was proposed by Yang to prevent heating, ventilation, and air conditioning errors. The reliability of polymer electrolyte membrane fuel cell had been surveyed by Whiteley et al. by FTA and FMEA risk assessment tools [13]. Varzakas studied special risks of quality control of food industries to ensure nutrition health by hazard analysis and critical control points [14]. Sayyadi Tooranloo et al. emphasized the importance of knowledge management in the source of failure identification by the fuzzy intuitive evaluation [15]. Liu et al. developed a model using fuzzy FMEA for weighting risk factors to integrating the analytic hierarchy process and entropy into the risk analysis of the general anesthesia process [16]. Omidvar and Nirumand (2016) investigated the process of equipment failures to identify the causes of processing adventures. They used the fuzzy VIKOR technique in their research to ranking failure modes [17]. Carbone and Tippett presented developed a new approach based on Risk FMEA to measure and analyze the project risks [18] and finally, Bazdar and Taheri studied a Bayesian customer risk model based on the operational characteristics to formulate a successful strategy for keeping customers satisfaction in 2020. In this research, Bayes risk of the customer is analyzed and used to classify customers according to the prior data. The proposed guidance to improving the production programming and sale management through the decision tree technique which is used as a case study about the products of Kaveh strong box Company [19].

In this research, the main goal is to remove one of the important problems of domestic industries that caused lots of failures, financial and human expenses in production procedure by the study of risk evaluation based on safety principles.

The remainder of this paper is organized as follows. Section 2 provides research methodology includes safety risk analysis and its applicable risk factors. Section 3 proposes a case study in the automotive part supplier industries, and finally, the last section concludes the paper.

\section{Safety risk analysis in the production process}

Quality assurance systems is presented in different names include a wide variety of techniques and tools to make sure of producing a perfect and competitive product. In this study, the Failure modes and effects analysis approach is selected from risk management methods because it is the analytical and applicable procedure and rule-based technique which is used to identify potential failure causes. The focus of this technique is to improve the security factor and ultimately customer satisfaction through preventing breakdowns. It is also the low-risk method to predict the problems and defects in designing and improving services and processes in organizations.

Because of process investigations during the production, process Failure modes and effects analysis is investigated out of different methods and was developed as an innovation in this study together with existing safety problems in the production line. In this way, the risk priority number is calculated by the multiplication of four factors including severity, occurrence, detection, and safety which range is from 1 to 10000 . After applying the suggested method and calculating the risk 
priority number, the corrective actions are defined to remove or reduce the risks in the production line which are done periodically to gain the new risk priority number and eventually compare it with the former one to get a result. to get cognition of how to analyse safety risks in the manufacturing process, we need to present the steps of this investigation. As shown in figure 1, the process chart of safety risk analysis is depicted. The safety risk assessment and the process failure modes and effect analysis are performed via parallel route and then RPN assessment and corrective action have been done.

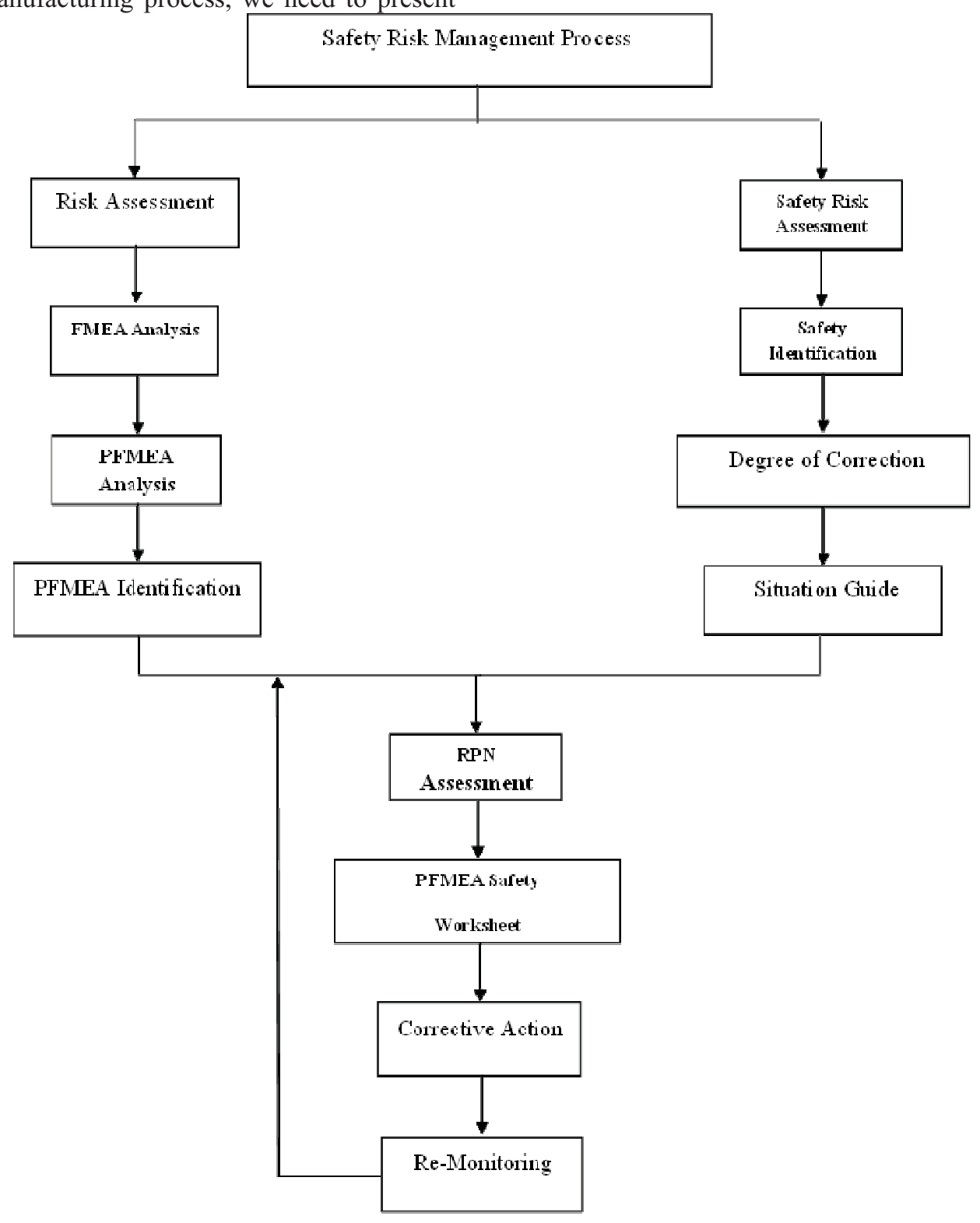

Figure 1. Safety Risk Management Chart

to investigate and rank the safety risks in the industry, the safety reference form is provided in the table (1). Generally harmful factors in the workplace are including physical, chemical, biological, and mechanical factors besides psychological factors of the operator and their sub-topics which are dangerous. The physical factors of the workplace are including noise, heat, coldness, light, fire, explosion, humidity, radiation, rays and radioactive materials, electrocution, pressure, and vibrations. The chemical factors of workplace are consisting of poisons, gases and steams, dust and metal smokes. The biological factors of the workplace are including microbes, viruses, parasites, and mushrooms. 
Table 1. Safety form

\begin{tabular}{|c|c|c|c|c|c|c|}
\hline $\begin{array}{c}\text { Correction } \\
\text { degree } \\
\text { (If yes) }\end{array}$ & No & yes & Preventing actions & Ranking & Example & Safety level \\
\hline NA & & $\begin{array}{l}x \\
\times\end{array}$ & $\begin{array}{l}\text { 1-1 Are the edges secured by guards? } \\
\text { 2-1 Are personal protective equipment } \\
\text { such as helmets used by the workers } \\
\text { while walking under a crane or } \\
\text { scaffolding? } \\
\text { 1-2 Is the right distance kept from } \\
\text { explosion point? } \\
\text { 2-2 Are colors and labels used to inform? }\end{array}$ & 10 & $\begin{array}{l}\text { 1. Collapse into } \\
\text { uneven surfaces } \\
\text { (mechanical factors) } \\
\text { 2. Explosion } \\
\text { (physical factors) }\end{array}$ & $\begin{array}{l}\text { The system is } \\
\text { really } \\
\text { unsecured. }\end{array}$ \\
\hline $\begin{array}{l}\text { NA } \\
\text { NA }\end{array}$ & & $x$ & $\begin{array}{l}\text { 1-3 Are personal protective equipment } \\
\text { used such as masks and gloves? } \\
\text { 1-4 Is a guard used in the cutting edge of } \\
\text { the machine? } \\
\text { 2-4 Is the right distance kept from the } \\
\text { moving part of the machine? } \\
\text { 1-5 Is the right distance kept from the } \\
\text { radiation source? } \\
\text { 2-5 Are the radioactive material sources } \\
\text { protected well? } \\
\text { 3-5 are the suitable protective equipment } \\
\text { used Such as thick protective layers, } \\
\text { rubber gloves and glasses? } \\
\text { 4-5 Are the protective signs used properly } \\
\text { to warn radiation? }\end{array}$ & 9 & $\begin{array}{l}\text { 3. Poisonous } \\
\text { (Chemical factor) } \\
\\
\text { 4. Body crushing } \\
\text { (Mechanical factors) } \\
\\
\text { 5. Radiation, rays, } \\
\text { radioactive materials } \\
\text { (Physical factors) }\end{array}$ & $\begin{array}{l}\text { System is not } \\
\text { safe. }\end{array}$ \\
\hline $\begin{array}{l}8 \\
3\end{array}$ & & $\begin{array}{l}x \\
\times\end{array}$ & $\begin{array}{l}\text { 1-6 Is there a first aid kit in the } \\
\text { workplace? } \\
\text { 2-6 Is there a fire extinguisher in the } \\
\text { workplace? } \\
\text { 1-7 Are respiratory protection equipment } \\
\text { used such as masks? } \\
\text { 1-8 Are respiratory protection equipment } \\
\text { used such as masks? }\end{array}$ & 8 & $\begin{array}{l}\text { 6. Fire } \\
\text { (Physical factors) } \\
\text { 7. Gases and steams } \\
\text { (Chemical factors) } \\
\text { 8. Poisonous moisture } \\
\text { (Chemical factors) }\end{array}$ & $\begin{array}{l}\text { System safety } \\
\text { is very low }\end{array}$ \\
\hline 3 & & $x$ & $\begin{array}{l}\text { 1-9 Is the right distance kept from the } \\
\text { cutting part of the machine? } \\
\text { 2-9 Is guarding used in the cutting part of } \\
\text { the machine? } \\
\text { 3-9 Are the protective signs used to show } \\
\text { the cutting risk? }\end{array}$ & & $\begin{array}{l}\text { 9. Hand cut } \\
\text { (Mechanical factors) }\end{array}$ & \\
\hline 3 & & $x$ & $\begin{array}{l}\text { 1-10 Is the right distance kept from the } \\
\text { moving part of the machine? }\end{array}$ & & $\begin{array}{l}\text { 10. Nip point } \\
\text { (Mechanical factors) }\end{array}$ & \\
\hline 8 & & $x$ & $\begin{array}{l}\text { 2-10 Is guarding used in the moving part } \\
\text { of the machine? } \\
\text { 3-10 Is there a first aid kit in the } \\
\text { workplace? }\end{array}$ & 7 & & $\begin{array}{r}\text { System safety } \\
\text { is low }\end{array}$ \\
\hline 6 & & $x$ & $\begin{array}{l}\text { 1-11 Are respiratory protection } \\
\text { equipment used such as masks? }\end{array}$ & & $\begin{array}{l}\text { 11. Metal smokes } \\
\text { (Chemical factors) }\end{array}$ & \\
\hline 3 & & $x$ & $\begin{array}{l}\text { 1-12 Are personal protective equipment } \\
\text { used Such as rubber or plastic shoes and } \\
\text { dielectric clothes? } \\
\text { 2-12 Is the machine equipped with an } \\
\text { earth wire? } \\
\text { 3-12 Is the workplace surface covered by } \\
\text { suitable covers such as wooden or rubber } \\
\text { carpets to remove the electricity from the } \\
\text { body? }\end{array}$ & & $\begin{array}{l}\text { 12. Electrocution } \\
\text { (Physical factors) }\end{array}$ & \\
\hline $\begin{array}{l}4 \\
6\end{array}$ & & $x$ & $\begin{array}{l}\text { 1-13 Are the under-pressure pipes } \\
\text { protected well? } \\
\text { 1-14 Are the personal protective }\end{array}$ & & $\begin{array}{l}\text { 13. Hydraulic and } \\
\text { pneumatic pipes } \\
\text { (Mechanical factors) }\end{array}$ & \\
\hline
\end{tabular}




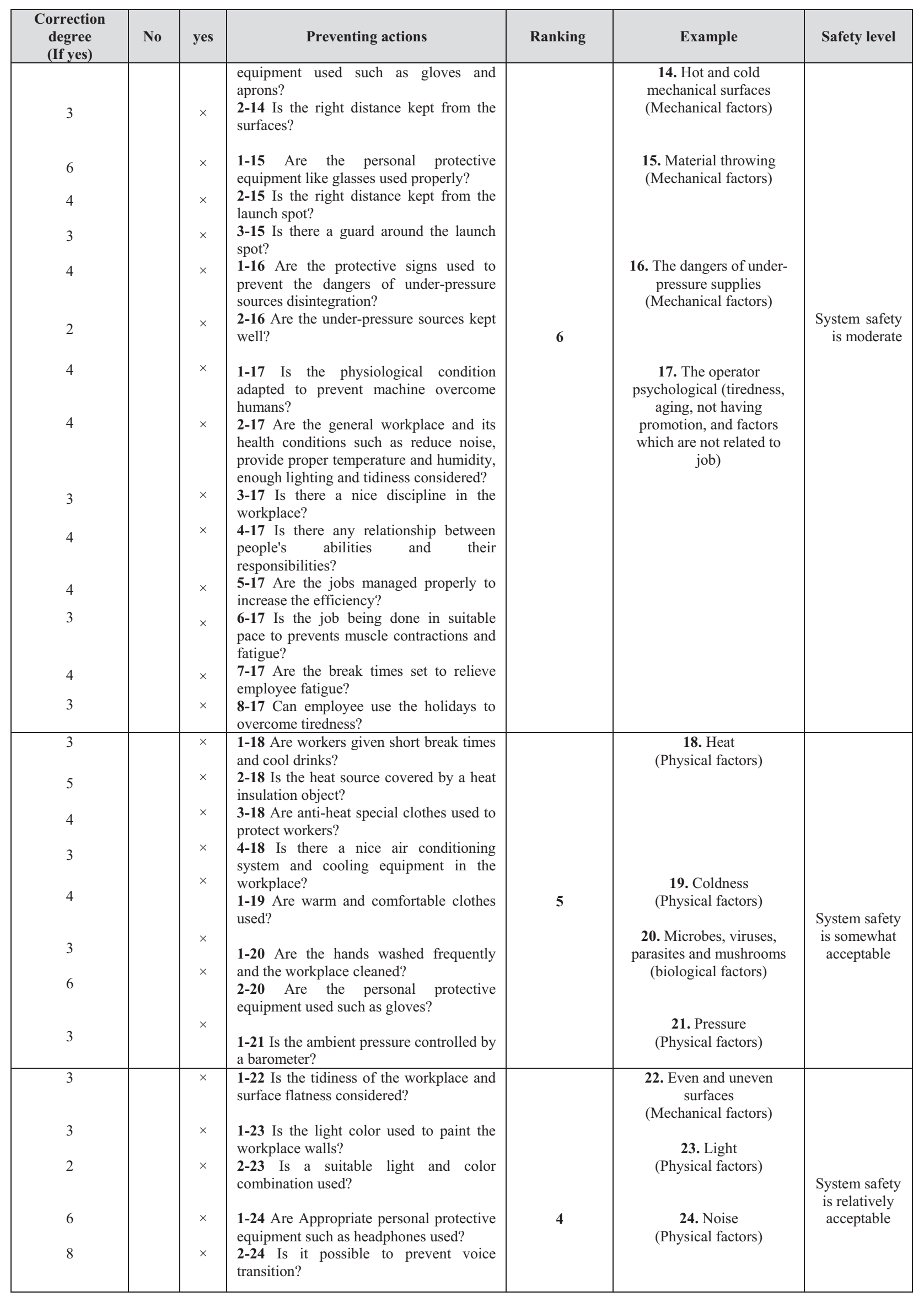




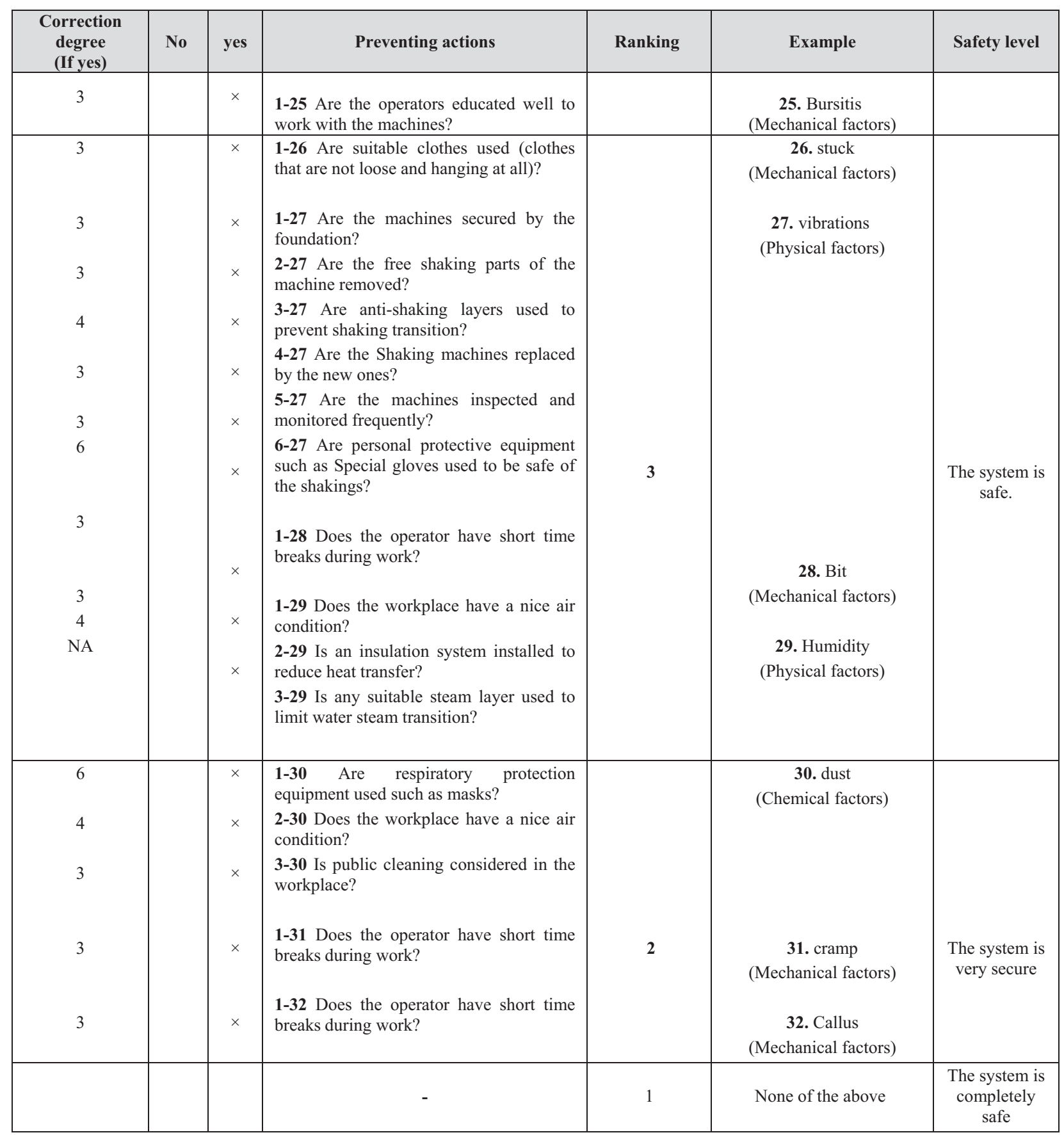

The mechanical factors include collapse into even and uneven surfaces, body crushing, hand-cut, nip point, hydraulic and pneumatic pipes, hot and cold mechanical surfaces, material throwing, the dangers of underpressure supplies, stuck and cramp. Finally, the psychological factors of operators that have been resulted from tiredness, aging forces, not having the promotion, and many other factors which are not related to the job.

Each of the mentioned risks is ranked in a special form according to their intensity. This form includes basic information such as the level of safety and many related examples. Also, the prevention actions are presented in another column as yes or no questions to remove or reduce the risks. If the answer is yes, the risk correction degree is expressed in the last column. Table 2 is presenting this classification and correction degree rate $[20,21,22]$. In the next section, we are going to apply this study in the production line of Zarfanar Company as a case of study.

Table 2. Risk Degree of correction

\begin{tabular}{|c|c|}
\hline \multicolumn{2}{|c|}{ Risk Degree of Correction } \\
\hline Rate & Ranking \\
\hline
\end{tabular}




\begin{tabular}{|c|c|}
\hline 1 & 90 to 100 percent of the risk is omitted. \\
\hline 2 & 80 to 90 percent of the risk is omitted. \\
\hline 3 & 70 to 80 percent of the risk is omitted. \\
\hline 4 & 60 to 70 percent of the risk is omitted. \\
\hline 5 & 50 to 60 percent of the risk is omitted. \\
\hline 6 & 40 to 50 percent of the risk is omitted. \\
\hline 7 & 30 to 40 percent of the risk is omitted. \\
\hline 8 & 20 to 30 percent of the risk is omitted. \\
\hline 9 & 10 to 20 percent of the risk is omitted. \\
\hline 10 & 0 to 10 percent of the risk is omitted. \\
\hline
\end{tabular}

\section{A case study in an automotive part production process}

Now it is time to apply the mentioned approach in this study. Therefore, Zarfanar Company, located in Golpayegan city in Isfahan province, which is the manufacturer of the Pride Anti-Roll Bar, etc., was selected as a case study in this study. Firstly, its operation process chart was analyzed. The company's production line is consisting of 25 workstations. According to figure (2), inspection and operation take place simultaneously in most stations, and in some stations, side operations are performed.
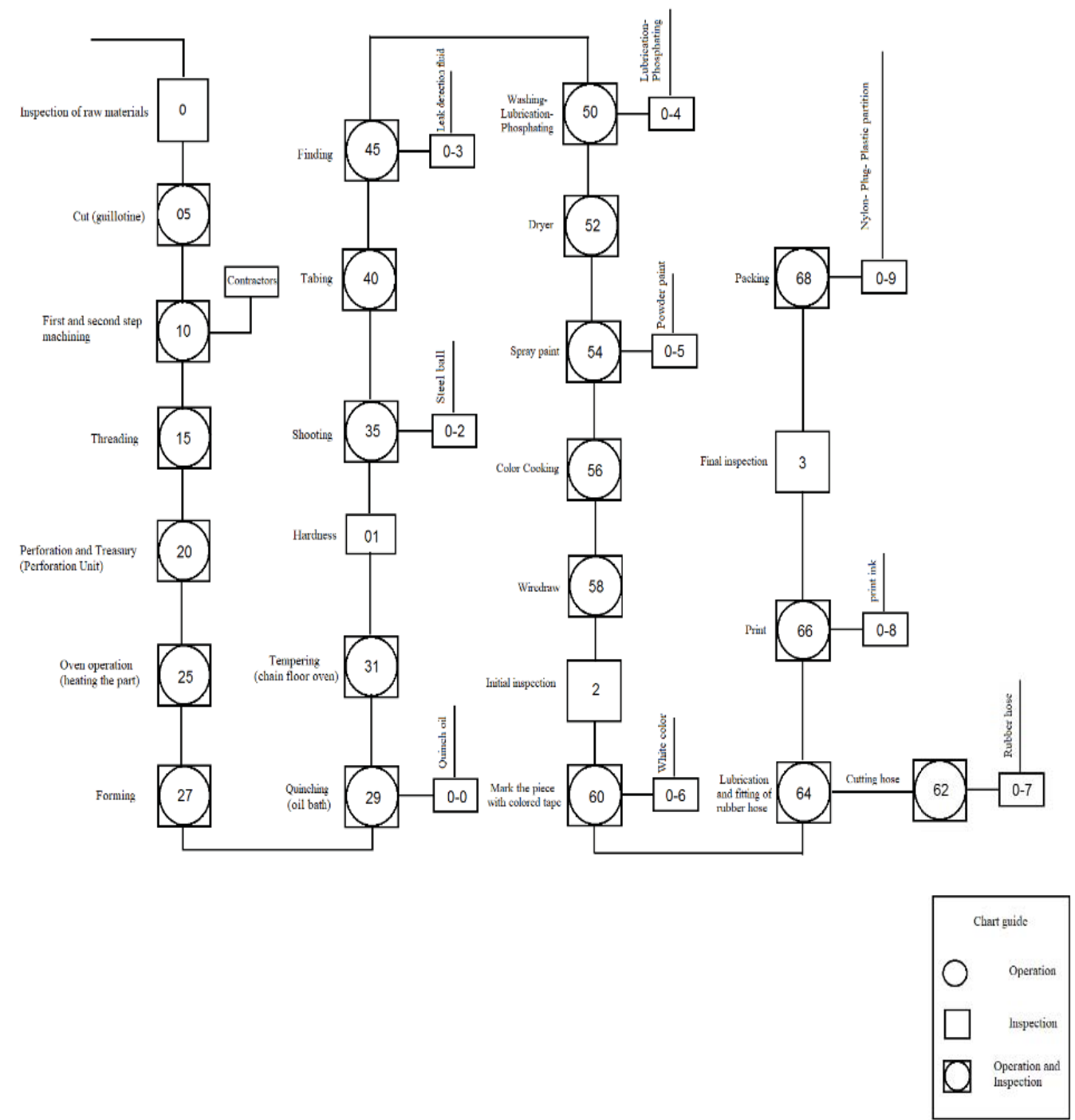

Figure 2. Operation Process Chart

To apply in this industry, we need an identification worksheet for the process failure modes and effect analysis and the reference safety form. It was comprehensively explained in the previous section. Now we will explain it in detail. The fishbone tool which includes $5 \mathrm{M} \& \mathrm{E}$ factors has been used to draw the identification worksheet. Table 3 includes columns called station name, OP number, process explanation, and risks classification, respectively. Risk classification is based on the fish bone tool and $5 \mathrm{M} \& \mathrm{E}$, the risks existing in each station according to their type were divided into manpower risk, material risk, measurement 
risk, machinery risk, method risks, and environmental (3). risk. The first station identification is presented in table

Table 3. The first station PFMEA identification

\begin{tabular}{|c|c|c|c|}
\hline Risk classification & Process explanation & $\begin{array}{l}\text { Number } \\
\text { OP }\end{array}$ & $\begin{array}{c}\text { Station } \\
\text { name }\end{array}$ \\
\hline $\begin{array}{l}\text { Man power: } \\
\text { The short length of the cut part which causes the loss and improper } \\
\text { operation of the part and it is the result of inappropriate setting and not } \\
\text { firming it. }\end{array}$ & \multirow{6}{*}{$\begin{array}{l}\text { In this station rebars are cut in standard } \\
\text { sizes to enter the next station. }\end{array}$} & \multirow{6}{*}{05} & \multirow{6}{*}{$\begin{array}{c}\text { Cut } \\
\text { (Guillotine) }\end{array}$} \\
\hline material risk: $\mathrm{NA}$ & & & \\
\hline $\begin{array}{l}\text { Measurement risk: } \\
\text { Non-calibration of measurement and visual error in using meter. }\end{array}$ & & & \\
\hline $\begin{array}{l}\text { Machinery risk: } \\
\text { Deformation in the cut part causes loss and customer dissatisfaction is } \\
\text { rooted in the slow guillotine and old machines. }\end{array}$ & & & \\
\hline $\begin{array}{l}\text { method risks: } \\
\text { Measurement error in using meter. }\end{array}$ & & & \\
\hline $\begin{array}{l}\text { Environment risk: } \\
\text { Operator improper ergonomics during work such as Excessive outpatient } \\
\text { work and back rotation }\end{array}$ & & & \\
\hline
\end{tabular}

Now worksheet of process failure modes and effect analysis is investigated. In the worksheet tab, some factors such as station name, op number, PFMEA date, station input, station output, and process feature of each station are mentioned. The worksheet includes 9 columns including risk, safety rank, severity, occurrence, detection, real risk priority number $\left(R P N_{\text {Real }}\right)$, relative risk priority number $\left(\mathrm{RPN}_{\text {Relative }}\right)$, risk situation, suggested corrective actions. Risks entered from the table (1) in the first column and the safety columns which are ranked according to the table (2) based on the opinion of the relevant expert. Also, severity, occurrence, and detection numbers are determined based on the opinion of the Zarfanar Company engineers.

One of The concepts which had been developed in this study is the impact of safety ranking on risk priority number. The range of this ranking is from 1 to 1000 but because of risk priority number is very low in the application, we increased it to 10,000 according to the following relation and also increased the other risk priority number in the same proportion. This relation indicates as follow:

$$
\frac{\text { RPN }_{\text {Max }}}{10000}=\frac{\text { RPN }_{\text {Real }}}{\text { RPN }_{\text {Relative }}}
$$

As an example, according to the above relation and table (5), RPN is $\left(216^{*} 10000\right) / 360=6000$ for the first risk. According to the table (4), the risk status column is defined. So RPN is critical between 7500 and 10000, is average between 5000 and 7500 , is low between 2500 and 5000 and is very minor between 0 and 2500. The minor risks disregard ordinarily.

Table 4. Risk situation guide

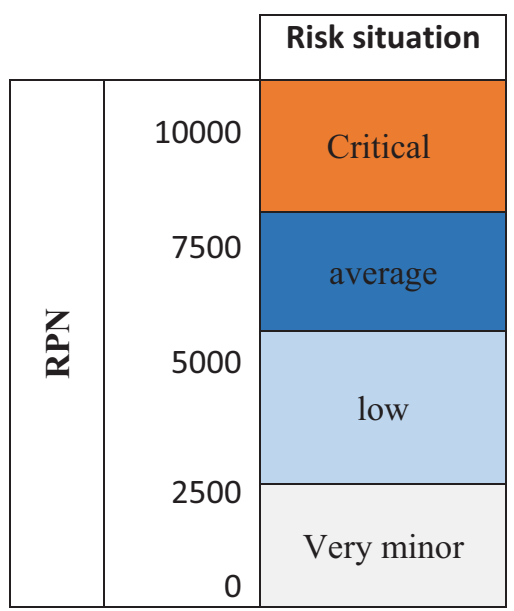


Table 5. The worksheet of process Failure modes and effect analysis of the first station

\begin{tabular}{|c|c|c|c|c|c|c|c|c|}
\hline \multicolumn{3}{|c|}{$\begin{array}{l}\text { Station name: Cut (Guillotine) } \\
\text { Station input: initial bullion }\end{array}$} & \multicolumn{3}{|c|}{$\begin{array}{l}\text { OP number: } 05 \\
\text { Station output: cut bullion }\end{array}$} & \multicolumn{3}{|c|}{$\begin{array}{l}\text { PFMEA implementation date: } 98.01 .27 \\
\text { process feature: cut length }\end{array}$} \\
\hline corrective actions & $\begin{array}{c}\text { Risk } \\
\text { condition }\end{array}$ & $\begin{array}{l}\text { Relative } \\
\text { RPN }\end{array}$ & $\begin{array}{l}\text { Real } \\
\text { RPN }\end{array}$ & Detection & occurrence & Severity & $\begin{array}{l}\text { Safety } \\
\text { rank }\end{array}$ & Risk \\
\hline $\begin{array}{l}\text { Point setting in the } \\
\text { beginning and middle of } \\
\text { the shift }\end{array}$ & & 6000 & 216 & 3 & 3 & 8 & 3 & $\begin{array}{l}\text { The short length of the } \\
\text { cut part which it is the } \\
\text { result of inappropriate } \\
\text { setting }\end{array}$ \\
\hline- & [ & 4000 & 144 & 3 & 2 & 8 & 3 & $\begin{array}{l}\text { The short length of the } \\
\text { cut part caused by not } \\
\text { firming the part }\end{array}$ \\
\hline- & - & 2666 & 96 & 2 & 2 & 8 & 3 & $\begin{array}{l}\text { Non-calibration of } \\
\text { measurement and visual } \\
\text { error in using meter. }\end{array}$ \\
\hline Buying a new guillotine. & & 5000 & 180 & 3 & 5 & 4 & 3 & $\begin{array}{l}\text { Deformation in the cut } \\
\text { part which is rooted in } \\
\text { the slow guillotine and } \\
\text { old machines. }\end{array}$ \\
\hline Use gage tools & - & 4000 & 144 & 3 & 2 & 8 & 3 & $\begin{array}{l}\text { Measurement error in } \\
\text { using meter. }\end{array}$ \\
\hline $\begin{array}{l}\text { Operator training and the } \\
\text { Use of equipment such as } \\
\text { footrests to maintain proper } \\
\text { ergonomics and operator } \\
\text { convenience }\end{array}$ & & 6666 & 240 & 3 & 2 & 8 & 5 & $\begin{array}{c}\text { Operator improper } \\
\text { ergonomics during work } \\
\text { such as Excessive } \\
\text { outpatient work and } \\
\text { back rotation }\end{array}$ \\
\hline
\end{tabular}

The worksheet of process failure modes and effect analysis related to the first station of Zarfanar industry is described in Table (5). After calculating the risk priority number and risk condition evaluation in the production line, corrective actions are defined about critical risks or intense risks. These actions will be done in a certain period (3- month, 6-month, etc.), and results in evaluation obtained from monitoring must be improved RPN. Otherwise, there will be some problems to implement actions. If the corrective actions which are chosen can be implemented correctly, process risks of the production line improve. Also, other risks (average, low, and minor risks) can be considered as a monitor reference for improvement.

After about 3 mounts of correction actions which are implemented in the manufacturing process of Zarfanar industry, we evaluated RPN again. If the correction actions have been done, the new RPN must be decreased. All information has been a drive from the engineering department and human resource management of Zarfanar Company. In this case study, four-station revised by many correction actions which have been defined at the engineering department. These stations are Cutting, Machining, Threading ,and Drilling. The mean improvement percentage at the cutting station is 9 percent. This improvement is resulted from point setting in the beginning, and middle of the shift, buying a new guillotine, using the gage tools, operating training and using the equipment such as footrests to maintain, proper ergonomics and the operator convenience. As be shown in Table (6), the RPN of most process risks in the cutting station is decreased by about 20 percent. This improvement is originated from the reduction of occurrence and detection grades. 
Table 6. Improvement percentage process FMEA at the cut station

\begin{tabular}{|c|c|c|c|c|c|c|c|c|}
\hline \multicolumn{3}{|c|}{$\begin{array}{l}\text { Station name: Cut (Guillotine) } \\
\text { date: } 1398.05 .06 \\
\text { Station input: initial bullion }\end{array}$} & \multicolumn{3}{|c|}{$\begin{array}{l}\text { OP number: } 05 \\
\text { Station output: cut bullion }\end{array}$} & \multicolumn{3}{|c|}{$\begin{array}{l}\text { PFMEA implementation } \\
\text { process feature: cut length }\end{array}$} \\
\hline $\begin{array}{c}\text { Improvement } \\
\text { Percent }\end{array}$ & $\begin{array}{c}\text { Risk } \\
\text { condition }\end{array}$ & $\begin{array}{l}\text { Relative } \\
\text { RPN }\end{array}$ & $\begin{array}{l}\text { Real } \\
\text { RPN }\end{array}$ & Detection & occurrence & Severity & $\begin{array}{l}\text { Safety } \\
\text { rank }\end{array}$ & $\begin{array}{c}\text { Risk } \\
\text { Number }\end{array}$ \\
\hline$\% 20$ & ] & 4000 & 144 & 3 & 2 & 8 & 3 & $\begin{array}{l}\text { The short length of } \\
\text { the cut part which } \\
\text { it is the result of } \\
\text { inappropriate } \\
\text { setting }\end{array}$ \\
\hline 0 & & 4000 & 144 & 3 & 2 & 8 & 3 & $\begin{array}{c}\text { The short length of } \\
\text { the cut part caused } \\
\text { by not firming the } \\
\text { part }\end{array}$ \\
\hline 0 & L & 2666 & 96 & 2 & 2 & 8 & 3 & $\begin{array}{l}\text { Non-calibration of } \\
\text { measurement and } \\
\text { visual error in } \\
\text { using meter. }\end{array}$ \\
\hline$\% 20$ & L & 3000 & 108 & 3 & 3 & 4 & 3 & $\begin{array}{l}\text { Deformation in the } \\
\text { cut part which is } \\
\text { rooted in the slow } \\
\text { guillotine and old } \\
\text { machines. }\end{array}$ \\
\hline$\% 13$ & [ & 2666 & 96 & 2 & 2 & 8 & 3 & $\begin{array}{l}\text { Measurement error } \\
\text { in using meter. }\end{array}$ \\
\hline 0 & & 6666 & 240 & 3 & 2 & 8 & 5 & $\begin{array}{l}\text { Operator improper } \\
\text { ergonomics during } \\
\text { work such as } \\
\text { Excessive } \\
\text { outpatient work } \\
\text { and back rotation }\end{array}$ \\
\hline
\end{tabular}

In the machining station, the mean improvement percentage is about 15 percent which is resulted from buying the $\mathrm{CNC}$ machine. In the next station, the threading station, the improvement percentage mean is about 7 percent which is resulted from the full control of the thread length by the circular gage. Finally, the mean of the improvement percentage at the drilling station is 21 percent which is rather than others. This improvement has resulted from a new design for the drilling machine, replacement drill birdie by drill, and full control of the location of the bore. Therefore, reduction in safety risks can be concluded by these results generally which is developed manufacturing process, production quality, and decreased the failure costs.

\section{Conclusion}

The main results obtained in this study are risk assessment of the production line process based on safety principles that causes a better and more comprehensive understanding of the risks in the automotive part supplier process. It helps us to make efforts to reduce safety risks and improve the productivity of the production line by defining relevant corrective action.

As it was mentioned in the previous section, we can apply the introduced method as a case study in the domestic industries of the country leading to risk identification, increasing customer satisfaction and thus increasing their selling rate and earning more profitability. Moreover, applying safety principles and quantifying it caused improvement in process and decreasing financial and physical failures and so lead manufacturing processes to high-quality production.

According to the results obtained from the risk priority number which was observed in the table (4), some of the risks are in crisis areas including forming stations and spray paint stations (RPN between 7500 and 10000). also, some corrective actions were defined to remove them and after a certain period, the process risks analysis is monitored. In this study, because of the time shortage of the case study, re-monitoring was not performed completely. It can be considered as a weakness of this research.

As mentioned in the case study section, in this research only four stations can be revised by correction actions after about three mounts. These stations 
encountered significant improvement between 10 and 20 percent which had been decreased safety risks and developed the quality of production process in Zarfanar Company.

Thus, it is suggested that to perform the process failure modes and effect analysis based on safety principles that have been developed in this study, the worksheet can be monitored over a defined period and results can be reevaluated to demonstrate the impact of this approach on reducing the manufacturing process risks.

\section{References}

[1] Yousefi, S., Alizadeh, A., Hayati, J. and Baghery, M., "HSE risk prioritization using robust DEA-FMEA approach with undesirable outputs: A study of automotive parts industry in Iran," Safety Science, 144-158, 2018.

[2] Guo, Q., Sheng, K., Wang, Z., Zhang, X., Yang, h., and Miao, R., "Research on Element Importance of Shafting Installation Based on QFD and FMEA," Procedia Engineering, 677-685, 2017.

[3] Wang, W., Liu, X., Qin, Yo., And Fu, Y., "A risk evaluation and prioritization method for FMEA with prospect theory and Choquet integral," Safety Science, 152-163, 2018.

[4] Peeters, J.F.W., Basten, R.J.I., and Tinga, T., "Improving failure analysis efficiency by combining FTA and FMEA in a recursive manner," Reliability Engineering and System Safety, 172, 36-44, 2017.

[5] Su, C. T. L., Hung C. T., Po, W., and Yang, T., "Improving the reliability of electronic paper display using FMEA and Taguchi methods," A case study: Microelectronics Reliability, 1369-1377, 2014.

[6] Chen, L., and Deng, Y., "A new failure mode and effects analysis model using Dempster-Shafer evidence theory and grey relational projection method," Engineering Applications of Artificial Intelligence, 13-20, 2018.

[7] Yang, C. S., Weiming, C., and Qiangqiang, G. B., "A practical solution for HVAC prognostics: Failure mode and effects analysis in building maintenance," Journal of Building Engineering, 26-32, 2018.

[8] Silva, M., Mendo De G., Paula Henriques, A., Thiago, P. S., Camara C. L., Seixas, C. A. P., "A multidimensional approach to information security risk management using FMEA and fuzzy theory," International Journal of Information Management, 733-740, 2014.

[9] Mangeli, M. S., Hosseinzadeh A., and Saljooghi F., "Improvement of risk assessment in the FMEA using nonlinear model, revised fuzzy TOPSIS, and support vector machine," International Journal of Industrial Ergonomics, 209-216, 2019.

[10] Sprearifico, C. R., Davide R. C., "A state-of-the-art review of FMEA/FMECA including patents," computer science review, 19-28, 2017.

[11] Kudláč, Š. Š., Vladimíra M. J., "Using the Saaty Method and the FMEA Method for Evaluation of Constraints in Logistics Chain," Procedia Engineering, 749-755, 2017.

[12] Villarini, M. C., Vittorio A., Lucrezia I. V., "Optimization of photovoltaic maintenance plan by means of a FMEA approach based on real data," Energy Conversion and Management, 1-12, 2017.

[13] Whiteley, Michael D., Jackson, S. L., "Failure Mode and Effect Analysis, and Fault Tree Analysis of Polymer Electrolyte Membrane Fuel Cells," International Journal of Hydrogen Energy, 1187-1202, 2015.

[14] Varzakas, T., "HACCP and ISO22000: Risk Assessment in Conjunction with Other Food Safety Tools Such as FMEA, Ishikawa Diagrams and Pareto," Encyclopedia of Food and Health, 295-302, 2016.

[15] Sayyadi Tooranloo, H., Ayatollah, Arezoo S., and Alboghobish, S., "Evaluating knowledge management failure factors using intuitionistic fuzzy FMEA approach," Knowledge and Information Systems, 183205, 2018.

[16] Liu, Hu C. Y., Jian X. Y., Xiao Y. S., and Meng M., “A novel approach for failure mode and effects analysis using combination weighting and fuzzy VIKOR method," Applied Soft Computing, 579-588, 2014.

[17] Omidvar, M., Nirumand, F., "An extended VIKOR method based on entropy measure for the failure modes risk assessment - A case study of the geothermal power plant (GPP)," Safety Science, 160-172, 2016.

[18] Carbone, Thomas A., Tippett, Donald D., "Project Risk Management Using the Project Risk FMEA," Engineering Management Journal, 16 (4), 28-35, 2015.

[19] Bazdar, A., and Taheri, N., "Bayesian customer risk model based on their operational characteristics in order to formulate a successful strategy for keeping customers," Sharif Journal of Industrial Engineering and Management, reference number 65-1/367/971012, 2020.

[20] Helm Seresht, P., and Del Pishe, E., "Occupational health," Chehr Publications, Third Edition, Tehran, 1388.

[21] Ghazaei, S., "Diseases and work complications," University of Tehran Press, Tehran, 1377.

[22] Golmohammadi, H., "Fire," Atlas press, 1369. 